\title{
FROM JUSTIFYING WAR TO JUSTIFYING PEACE: A HISTORICAL OVERVIEW OF THE DISCOURSE IN ECUMENICAL CIRCLES $(1905-2014)$
}

\section{Mary-Anne Plaatjies Van Huffel}

Department of Systematic Theology and Ecclesiology, University of Stellenbosch mapvanhuffel@sun.ac.za

\section{ABSTRACT}

Justice and peace have been central concerns for the World Council of Churches (WCC) since its foundation in 1948. A notable transition from a just-war position to a just-peace position has taken place during the course of time. This paper will attend to statements regarding just war and just peace, justice, peace, armaments and disarmaments issued during the past decades, as well as the Historic Peace Churches' influence on the discourse. At the end of the paper I will attend to the changeover of the global culture of violence in the direction of a culture of just peace and the movement of peace to the centre of life and witness of the church. Earlier the WCC embraced the theory of just war - currently just peace is being underscored. The Historic Peace Churches played a pivotal role in this transformation.

Keywords: World Council of Churches; just peace; just war; pacifism; crusade; Historic Peace Churches; armaments; disarmaments

\section{INTRODUCTION}

Three attitudes to war and peace surface in Christian ethics, namely pacifism, just war and the crusade (Bainton 1982, 14). According to Bainton, pacifism is often associated with withdrawal; just war is associated with qualified participation; and the crusade is associated with dominance of the church over the world (Bainton $1982,15)$. The object of just war is the vindication of justice and the restoration of

\section{UNISA}


peace (Bainton 1982, 33). Religion is seen as a justifiable motivation to wage wars, inter alia holy wars and crusades between Protestant and Catholic states and against people of other religions. These three views had taken shape before the close of the Middle Ages.

The devastating aftermaths of World War I (1914-1918), World War II (19391948), the Cold War (1940s-1990s), the upsurge of terrorism, the emergence of cyber warfare and drone strikes, compelled the World Council of Churches (WCC) to reposition herself from a just-war position to a just-peace position. Disarmament became an issue when the leaders of the churches and the ecumenical movement became aware of the atomic age, starting with the bombing of Hiroshima and Nagasaki by the USA in August 1945.

\section{WHAT IS THE JUST-WAR THEORY?}

The just-war theory in Western Christianity is attributed to Augustine de Hippo (354$430 \mathrm{CE}$ ) and Thomas Aquinas (1225-1274 CE). Augustine wrote in depth on topics related to war. For example, in his City of God he stated the following:

As, then, there may be life without pain, while there cannot be pain without some kind of life, so there may be peace without war, but there cannot be war without some kind of peace, because war supposes the existence of some natures to wage it, and these natures cannot exist without peace of one kind or other. (Schaff 1994, 97)

Thomas Aquinas fused Augustine's arguments regarding justifiable warfare into a clear set of principles, as seen in his Summa Theologica (Loetcher 1944, 313325). Aquinas presents the general outline of what is currently known as the justwar theory. According to Aquinas, the main Christian objection to war is based on the belief that war is contrary to God's wishes and is always sinful. According to Aquinas a just war requires authority, a just cause, primarily a guilty enemy and a good intention to promote good or to avoid evil (Ferguson 1977, 110). In the justwar theory two conflicting propositions on war and peace are being reconciled, namely: on the one side purposeful taking of human life is wrong; but on the other side states have a duty to defend their citizens and to promote justice. The just-war theory attempts to lay out the conditions under which states can justifiably go to war. According to Ferguson $(1977,109)$ Gratian introduced the concept of just war into modern international jurisprudence. About $1140 \mathrm{CE}$ Gratian compiled a volume entitled Concordia Discordantium Canonum, generally known as the Decretum. This is a major document in the history of Christian thinking about just war. According to Gratian, military service is not inherently sinful; its proper purposes are to repel injuries and to inflict punishment. A war is therefore, according to Gratian, just if undertaken to repel enemy aggression or to recover stolen property; to avenge injuries through an authoritative edict; and to assert a legal right. War, according to Gratian, requires authority, obedience, and a just cause. Gratian's views were taken 
up by Rufinus in 1157 CE. According to Rufinus, a war was just in terms of three people: the declarer, the soldier and the enemy. It must be declared by a properly instituted authority, fought with worthy zeal, and directed against a guilty party (Ferguson 1977, 109).

Three just-war principles can be discerned, namely; jus ad bellum (justice to war); jus in Bello (justice in war); and jus post bellum (justice after war). Jus ad bellum has to do with going to war in the first place, jus in bello addresses how one should act while at war, whilst jus post bellum is concerned with just terms at the close of a war (Williams 2006, 309-320). For centuries Christianity at large embraced the just-war theory and justified how and why wars are fought, for example the Crusades (1095-1291 CE), French Wars of Religion (1562-1598 CE), and the Thirty Years War (1618-1648 CE). Today, just-war principles are most often used for determining whether going to war is justified (jus ad bellum). The following are regarded as justwar principles (jus ad bellum): ${ }^{1}$

a. Proper authority: A war is just only if waged by a legitimate authority (legitima potestas) (Yoder 1996, 148). Criteria for a legitimate ruler include, amongst others, dynastic decent from a previous ruler or election according to custom or constitution, while legitimacy may be forfeited by being a bad ruler or tyrant, and religious heresy may be held to disqualify a ruler. Just causes cannot be served by actions taken by individuals or groups who do not constitute an authority sanctioned by whatever the society and outsiders to the society deem legitimate. Individuals can seek redress of his/her rights from the tribunal of his/her superior. Only a soldier under oath and under the control of the sovereign may fight. Clergy, the religious and penitents are excluded or dispensed (Yoder 1996, 149). Those in authority are supposed to protect the people. It is lawful for them to use weapons or force to keep peace and order inside their city/ country and to punish people who break the laws and do evil. In the same way, those in authority are responsible for defending the community against external enemies, and can therefore use force against enemies.

b. Just cause (causa justa)/right intention (recta intentio): The cause must be just. The offence must be actual, not only possible; intentional, not inadvertent or unintended or an honest error; of substantial importance; objective, verifiable, as a fact; unilateral, not provoked (Yoder 1996, 150). A war may be fought only with a right intention (Yoder 1996, 152. A just war must be fought only for purposes of self-defence against armed attack or to right a serious wrong. A just war can only be fought to redress a wrong suffered. For example, self-defence against an armed attack is always considered to be a just cause (although the justice of the cause is not sufficient). The offence may be an aggression demanding defence or a threat demanding deterrence; an injustice demanding reparation such as seizure of property; denial of free passage on land or sea; breach of treaty obligations; insult to honour of nation or sovereign (Yoder 1996, 151).

1 Cf. the list of criteria of the just-war tradition compiled by Yoder in When war is unjust: Being honest in just-war thinking 1996, 147-163; Williams, R. 2006. Jus Post Bellum: Just war 2006, 309-320; Introducing the principles of just war theory. http://istep.sdsu.edu/documents/ Lesson\%205\%20Intro\%20to\%20Just\%20War\%20Theory.pdf (accessed 1 June 2015). 
There must be a just cause (causa justa) for the war. Heresy, blasphemy, offences against the honour of God; violation of the laws of nature and the rights of peoples, had been seen in the past as just cause for punishment (Yoder 1996, 151). The premise was that those who are assaulted should be attacked because they deserve it on account of some fault. Those fighting must have a rightful intention, so that they intend the advancement of good, or the avoidance of evil. Further, a just war can only be fought with 'right' intentions: the only permissible objective of a just war is to redress the injury. The belligerents should have a rightful intention, to advance good or to avoid evil (Ferguson 1977, 111). The first object of just war is the vindication of justice. Plato defines justice as 'giving to each his due' (Bainton 1982, 38). Intention must be justified in terms of the global common good. National honour, territorial or commercial expansion and the weakening of the enemy regimes are not seen as valid ends (Yoder 1996, 152).

c. Last resort: A just war must be the last resort after everything else has been tried (Ferguson 1977, 111; Yoder 1996, 154). A just war may be waged as a last resort against an offence committed against a third nation. In this cause a third party intervenes on humanitarian grounds on behalf of innocent subjects (Yoder 1996, 151). The recourse to war is seen as the last resort after mediation failed (Bainton 1982, 33). All peaceful options must be exhausted before the use of force can be justified.

d. Probability of success: A war can only be just if it is fought with a reasonable chance of success (Ferguson 1977, 111). The war must be winnable, otherwise one suffers both evils (the evil to be prevented and the evil of war) (Yoder 1996, 155). The enemy must always be able to sue for peace. The goal of war should not be unconditional surrender (Yoder 1996, 155). Deaths and injury that result from a hopeless cause cannot be morally justified. To pursue war beyond reasonable redress, or when the enemy has offered to negotiate, makes a previously valid cause unjust (Yoder 1996, 155).

e. Beneficial outcome: The outcome of the war must be better than the situation that would exist, had the war not taken place. The entire war must promise to be proportionately prudent, that is, to cause less harm than the harm it seeks to prevent (Yoder 1996, 155). The ultimate goal of a just war is the restoration of peace. The object of war is peace (Bainton 1982, 33; Yoder 1996, 152). Peace established after the war must be preferable to the peace that would have prevailed if the war had not been fought (Schaff 1994, 97).

f. Proportionality: The war must be fought by the use of legitimate means. The means must be indispensable. It should be the only way necessary. Unnecessary combat is to be avoided, even in a just cause (Ferguson 1977, 111; Yoder 1996, 156). The violence and destruction must be proportional to the injury suffered (Yoder 1996, 156). During combat no unnecessary death or wanton destruction may be inflicted (Yoder 1996, 156). States are prohibited from using force not necessary to attain the limited objective of addressing the injury suffered. The weapons used in war must discriminate between combatants and non-combatants. The means must respect the immunity of the innocent (Yoder 1996, 157). Civilians, women, children, the aged, infirmed, unarmed persons, or neutral third parties are never permissible targets of war and every effort must be taken to avoid killing the innocent (Yoder 1996, 157). The deaths of civilians are justified only if they are unavoidable victims of a deliberate attack on a military target. 
g. The means must be discriminating: If any weapon, any strategy, any military unit becomes uncontrollable, then that abandonment of discrimination infringes in principle upon the discipline of necessary and legitimate means, even if the illicit actions have not yet been taken (Yoder 1996, 158). The amount of violence should be restricted to the minimum necessary (Bainton 1982, 58). If any government or command centre says it intends to strike indiscriminately, that is already immoral as intention, even though it has not been carried out (Yoder 1996, 158).

h. Lastly, the means must respect the provisions of international law. There should be respect for international law, customs, treaties, and international agenda (Yoder 1996 155). For example the articles XXII and XXIII of Convention IV of The Hague (1907) to employ poison or poisoned weapons; to kill or wound treacherously individuals belonging to the hostile nation or army; to kill or wound an enemy who, having laid down his arms, or having no means of defence, has surrendered; to declare that no quarter will be given; to employ arms, projectiles, or material calculated to cause unnecessary suffering; to make improper use of a flag of truce, of the national flag, or military insignia and uniform of the enemy, as well as the distinctive badges of the Geneva Convention (e.g., Red Cross) ( Yoder 1996, 159).

A war is seen as justifiable only if it meets all the above criteria. Taking all these criteria into account, it seems today as if a truly 'just war' is quite near impossible to ascertain. Ferguson $(1977,11)$ rightly identifies the main disadvantage of the above doctrine of just war, namely: there is no objective tribunal to declare a cause just. The authority declaring 'just' war is advocate, judge, jury and executioner. Objectively, war can be just only on one side (Yoder 1996, 156). For centuries Christian nations have been fighting wars that are in their views, based on the doctrine of just war.

\section{THE FOUNDING STAGES OF THE WCC AND THE QUEST FOR JUSTICE AND PEACE}

One can rightly say that the united ecumenical peace movement began at the World Peace Conference in Lucerne, Switzerland in $1905 .^{2}$ Delegations from the United States, Great Britain, France, Germany, Switzerland, Austria, Denmark, the Netherlands, Italy, Belgium, China, Spain, Hungary, Monaco, Russia and Sweden attended the conference. Altogether some 120 organisations were represented. The congress approved unanimously the proposition for the creation of a regular congress of the nations as well as propositions for a limitation of armaments and the conclusion of a general treaty of obligatory arbitration. This congress was seminal in the future developments of a regular congress of the nations. Nevertheless, an international conference held in August 1914 in Konstanz, Germany, was interrupted due to the outbreak of the First World War.

2 Early Journal Content on JSTOR 1905, p. 190-1991. http://archive.org/stream/ jstor-25752575/25752575_djvu.txt_(accessed 1 June 2015). 
The evolution of the ecumenical thinking about justice and peace and creation is especially noticeable in the World Alliance of International Friendship and Life and Work which was founded at Constance in August 1914 with the help of the Church Peace Union. The Alliance worked predominantly in and through the churches and in association with the other branches of the ecumenical movement for the cause of peace. The main objective of the World Alliance was to help substitute reason and arbitration for war as a means of settling international disputes by cooperating with many secular agencies, churches, colleges, schools and other groups working for the attainment of collective security and a just and abiding peace. ${ }^{3}$ The Life and Work movement represents the attempt of Protestant and Orthodox churches to reach consensus on the church's universal practical role in society. The movement began with a preliminary conference held in 1920 in Geneva, and culminated in two world councils namely the Universal Christian Conference on Life and Work held in Stockholm in 1925, and the Oxford Conference on Church, Community and State Oxford, England in 1937. The purpose of the Stockholm Conference, 1925, was to emphasise the churches' responsibility to cooperate with all people of goodwill in working for peace and a better social order. ${ }^{4}$ The Stockholm Conference, 1925, tried to find a common basis for the churches to renew their efforts on behalf of peace and justice. The churches were invited to dedicate themselves anew to the task of witnessing to the power of the gospel in all realms of life, in industry, society, politics and international relations. A continuation committee carried on the work of the Stockholm Conference through several meetings and research activities. The Council for Life and Work was incorporated into the preliminary founding stages of the WCC.

War and its after effects prompted Christian leaders to define a new global order, one based on a 'just and durable' peace and centralised around human rights (Nurser 2003, 1). In 1928 the World Alliance issued a joint statement, namely The EisenachAvignon Resolution, Eisenach, Germany. This resolution condemned war as a tool of international power politics. The settlement of international disputes by war was seen as irreconcilable with the spirit of Christ, and therefore irreconcilable with the spirit and conduct of His church. ${ }^{5}$ In 1929 an attempt was made to outlaw war by treaties between sovereign states (Bainton 1982, 214). For example the KelloggBriand treaties (officially General Treaty for Renunciation of War as an Instrument of National Policy) were signed by 59 nations. All these developments influenced the

3 World alliance for promoting international friendship through the churches 1909-1948. http:// archives.wcc-coe.org/query/detail.aspx?ID=40897 (accessed 1 June 2015).

4 Peace and disarmament. Documents of the World Council of Churches. 1982:16-17. Disarmament on the WCC agenda 2003, 2. http://ploughshares.ca/wp-content/uploads/2003/11/ WCCandDisarmament.pdf (accessed 1 June 2015).

5 Eisenach-Avignon Resolution, Eisenach, Germany, 1928. http:/www.skr.org/wp-content/ uploads/2013/10/Worldpeacemap_131017_high_utfall_sk\%C3\%A4rm\%C3\%A4rken.pdf (accessed 1 June 2015). 
decision on just war of the first WCC Assembly which, due to World War II, could only constitute in 1948.

\section{WORLD WAR II AND THE FIRST WCC ASSEMBLY}

Ever since its foundation in 1948 the WCC, in Amsterdam Netherlands, has spoken out for and intervened in the interest of justice and peace (Eastman 1949, 675). The first WCC Assembly took place whilst World War II was raging. This Assembly has been described as the most significant event in church history since the Reformation (Eastman 1949, 674-675). The devastating effects of the war had an effect on the decisions of the Assembly on justice and peace. The theme of the meeting in Amsterdam 1948 was Man's disorder and God's design. Four main themes had been discussed at the Assembly, namely: (1) An international legal order; (2) The EastWest tension; (3) Human rights; (4) Power, war and peace (Eastman 1949, 675). The delegates at the WCC had a deep desire to overcome the root causes of war. The need to look beyond national interests was recognised. Emphasis was given in the WCC to the importance of international law which all nations should respect. The WCC encouraged the codification of international law, the use of existing international machinery, and the creation of such institutions as shall further the establishment of an international legal order that all people 'may lead a quiet and peaceable life' (I Tim. 2:2) (Eastman 1949, 676). War as method of setting disputes was seen as incompatible with the teaching and example of Jesus Christ. ${ }^{6}$ The premise of the Assembly was that war was a sin against God and a degrading of man. Therefore the WCC affirmed that war is contrary to the will of God. The WCC recognised both the horror of nuclear power and the destructiveness of conventional armaments and condemned the whole conduct of modern warfare. It requested the churches to support any effort dealing specifically with the use of atomic power and the multilateral reduction of armaments. ${ }^{7}$ Furthermore, the WCC declared unequivocally that the tradition of a just war requiring a just cause and the use of just means is being challenged. ${ }^{8}$ The inescapable question for the WCC was: Can war now be an act of justice? The Assembly was unable to answer this question unanimously. Three broad positions were maintained by the member churches, namely: (1) Those who hold that modern warfare, with its mass destruction can never be an act of justice; (2) Those who hold that citizens must be distinctly taught that it is their duty to defend the law by force if necessary; (3) Those who refuse military service of all kinds. ${ }^{9}$ Though Amsterdam condemned war as contrary to the will of God, it also recognised

6 Report of Section IV, The church and the international disorder, Official Report of the First Assembly, Amsterdam, 1948, WCC, Geneva, p. 89. Just peace companion (second edition). 2012. Geneva: WCC.

$7 \quad$ Peace and disarmament 1982, 1.

8 Ibid, 1982, 15.

9 Ibid, 1982, 16-17. 
the wide differences held by the churches vis-à-vis the question of war as a means of achieving justice. The Assembly therefore declared that the churches should condemn the causes of war by promoting peaceful change and the pursuit of justice; maintaining good faith and the honour of the pledged word; resisting the pretensions of imperialism; promoting the multilateral reduction of armaments; combating need and despair; and promoting spiritual resistance (Eastman 1949, 676). Three positions developed as opposing positions of conscience regarding the question of war and peace, namely:

a. The classical pacifism, which refuses in obedience to the faith any participation in war and which opts for active peace service in the place of military force.

b. The position of the classical ethics of the state, which holds that the state, as a divinely instituted order of preservation, must be ready to use force in order to defend justice, and can oblige Christians to take up weapons to defend their country.

c. The position based on a rigorous application of the just-war doctrine. ${ }^{10}$

The Amsterdam Assembly took place on the eve of the Cold War and thus the following years were characterised by continual ecumenical attempts to promote the cause of disarmament (Miller 2013,2). Numerous statements were issued in this regard. The development of military technology, and especially atomic, radiological, biological and chemical arms and the means to deliver them, marks a decisive turning point in the history of mankind, of states and their war. ${ }^{11}$ Indiscriminate war became a reality. This forced Christians to re-exam previous thinking concerning war and peace. The WCC and the WCC's Commission for International Affairs (CCIA) have sought to encourage the solution of international disputes by methods other than war, inter alia disarmaments or international control of armaments and the support of institutionalised measures for peaceful change, peace-keeping and peaceful settlement. ${ }^{12}$ From 1945 to 1991 the Cold War dominated international affairs. Every Assembly of the WCC during and thereafter addressed the issue of justice and peace.

In 1951 the CCIA issued a statement entitled Churches stand for peace, declaring that 'we must neither purchase peace at the price of tyranny nor in the name of justice look on war as a way to justice or as a ground of hope' (Van den Bent 1986, 19). This statement set the WCC on a new path toward just peace. The statement states clearly that it is a Christian duty to seek both peace and justice and they should do all in their power to prevent tensions and limit conflicts which may lead to a third world war. The CCIA condemned the proposal of preventative war or the use for

10 The development of common positions on justice, peace and creation in the ecumenical movement. http://oikoumene.net/hostudies/gerecht.book/one.book/index.html?entry=page. book.1.2.5 (accessed 1 June 2015).

11 Peace and disarmament 1982, 55.

12 Ibid, 1982, 59. 
aggressive purposes of atomic weapons. The premise of the CCIA was that world peace and justice require international organs of law and order. ${ }^{13}$ The CCIA argued that the United Nations and its agencies were in the best position to develop the rule of law over the nations. After World War II several international bodies were constituted and law was approved for means of solutions of disputes and conflicts for example the United Nations (UN), the International Court of Justice and the Universal Declaration of Human Rights. The CCIA played a pivotal role the drafting of major $\mathrm{UN}$ documents such as the Universal declaration of human rights and the two international covenants on human rights (Howell 1982, 37). The CCIA, having consultative status with various UN bodies, indefatigably represented the churches in the concern for disarmament. ${ }^{14}$ In 1952 the CCIA welcomed the action of the UN General Assembly at its sixth session to establish under the Security Council a Disarmament Commission. ${ }^{15}$

The WCC General Assembly at Evanston in 1954 adopted a resolution regarding the prohibition of all weapons of mass destruction under the provision of international inspection and control along with the reduction of all types of armaments. ${ }^{16}$ The WCC affirmed in the statement Christians in the struggle for world communion that it is not enough for churches to proclaim that war is evil. The WCC urged churches to study afresh the Christian approaches to peace, taking into account both Christian pacifism as a mode of witness and the conviction of Christians that in certain circumstances military action is justifiable. ${ }^{17}$ These deliberations had some bearing on the WCC's notion on justice and peace. The WCC called upon all nations to refrain from all weapons of mass destruction, including atomic and hydrogen bombs. ${ }^{18}$ The WCC was convinced that peace will be endangered so long the armaments race continues and so long as any nation seeks to extend its power by the threat or use of military force. ${ }^{19}$

The CCIA executive committee issued a statement on Disarmament and peaceful change which was adopted by the Central Committee of the WCC in 1955 (Van den Bent 1986, 19). In this statement the WCC emphasised the urgency to devise a system of inspection and control of the reduction of disarmaments. ${ }^{20}$ In 1957 WCC general secretary, Visser't Hooft, called for non-violent Christian peace witness in light of the war in Algeria. In the same year the CCIA issued a statement on Atomic tests and disbarment which set forth a programme featuring the banning of atomic tests (Van den Bent 1986, 19). The WCC Central Committee was divided in its opinion

13 Ibid, 1982, 17.

14 Ibid, 1982, 85

15 Ibid, 1982, 19-20.

16 Ibid, 1982, 2

17 Ibid, 1982, 21.

18 Ibid, 1982, 22-22.

19 Ibid, 1982, 23.

20 Ibid, 1982, 26. 
on the issue. ${ }^{21}$ On 12 August 1957 Eirene, International Christian Peace Service, was founded as a means to give peace theology a practical expression in solidarity with the marginalised and oppressed. By 1958 it became clear that the nations had not made decisive progress towards disarmament and/or the cessation of atomic testing. ${ }^{22}$ The WCC Central Committee, however, took note with gratitude that the governments producing atomic weapons had taken a first step towards bringing the testing of atomic weapons under international control. ${ }^{23}$

In its report to the New Delhi Assembly in 1961, the CCIA stated that the elimination of war, though especially in the context of nuclear power essential to the future survival of mankind, would not solve all the problems (Van den Bent 1986, 20). The WCC appealed to all governments to halt the race in arms and to cease nuclear testing. ${ }^{24}$ Although complete and general disarmament was still the accepted goal of the WCC, it was realised that it had to be seen as a goal. ${ }^{25}$ In 1963 the WCC welcomed the Treaty banning nuclear weapons tests in the atmosphere, in outer space and underwater as the first constructive international agreement regarding nuclear testing. ${ }^{26}$ The WCC also took cognisance that the Treaty does not halt the production or reduce existing stockpiles of nuclear weapons. However, it believed that it may slow up the nuclear arms race and would diminish the health hazards from radioactive fall-out. ${ }^{27}$ Notwithstanding the Treaty, the arms race continued unabated. ${ }^{28}$ The WCC Central Committee appealed to all nations which had not acceded to the partial Test ban treaty to join the rest of the community of nations in order to make the treaty universally applicable. ${ }^{29}$ The WCC urged that governments who had not become parties to the Geneva Conventions of 1949 should do so, and that those who had become parties should honour their commitment. ${ }^{30}$

In 1968 the Fourth Assembly of the WCC at Uppsala reaffirmed the declaration of the Amsterdam Assembly 1948. It declared that it was a duty of the churches to press for the prevention of war, a halt of the arms race, and the cessation of experiments concerning mass destruction by chemical and biological means. The WCC also advocated for the abandonment of the initial use of nuclear weapons. ${ }^{31}$

In 1968 the WCC Central Committee, Canterbury, voted to establish a Programme to combat racism (PCR). The Central Committee created a special fund

21 Ibid, 1982, 3.

22 Ibid, 1982, 31.

23 Ibid, 1982, 33.

24 Ibid, 1982, 37.

25 Ibid, 1982, 6.

26 Ibid, 1982, 46.

27 Ibid, 1982, 46.

28 Ibid, 1982, 51.

29 Ibid, 1982, 53.

30 Ibid, 1982, 59.

31 Ibid, 1982, 9, 61. 
to be used to make grants to organisations of oppressed racial groups and victims of oppressed groups to be used in their struggle for economic, social and political justice (Howell 1982, 98.). The WCC justified theologically their involvement in the liberation struggles of people across the globe; amongst others liberation movements like the African National Congress and the Patriotic Front of Zimbabwe received funding from the Special fund of the programme to combat racism (Howell 1982, 100). The Program to combat racism has been one of the controversial initiatives of the WCC. The Special fund was heavily criticised, even amongst member churches. In 1969 a consultation on the alternatives to conflict in the quest for peace took place at the Ecumenical instate in Bossey. According to Anwar Barkat (1970) the church should support those who object on grounds of conscience to service in particular wars and to press for national legislation on this point and the development of alternative forms of community service, at home and abroad, which will contribute to the growth of peace, justice and understanding (Barkat 1970, 31). With gratitude cognisance had been taken in 1969 that the United Nations General Assembly unanimously passed a resolution on disarmament.

A shift to just peace emerged especially during the 70s. In 1973 the WCC issued a document Violence, nonviolence and the struggle for social justice. The premise of the document is, firstly that non-violence is the only Christian method, and secondly that violence is permitted in extreme circumstances. Thirdly, that those in situations of violence cannot help but react with violence. According to Ferguson (1977, 120) there should be just cause, the exhaustion of other possibilities, a reasonable expectation of attaining the desired ends, just methods and a positive concept of the ensuing order. In 1973 the CCIA took cognisance that the militarisation of the world continues unabated. They appealed to the member churches, and indeed to all Christians, to become more involved in the struggle for world disarmament. ${ }^{32}$

The main theme of the Fifth Assembly of the WCC in Nairobi Kenya, 1975, was liberation from political, economic, social and personal oppression (Nichols 1976, 73). The Assembly in Nairobi took place at the end of the Vietnam War. Justice and peace was seen by the WCC as equal to the will of God. The Assembly affirmed the peace-building task of the churches and its necessary engagement for disarmament (Van den Bent 1986, 22). The WCC made an appeal to the Central Committee of the WCC to initiate a consultation on disarmament, which should investigate and compare available material on the arms race and the technological, economic, environmental and military implications. ${ }^{33}$ Furthermore, the WCC called upon the newly elected Central Committee to share the experience of the Historic Peace Churches with the member churches. ${ }^{34}$ From then on notions of the Historic Peace Churches on just peace influenced decisions of the WCC. Taking up the spirit

32 Ibid, 1982, 69-70.

33 Ibid, 1982, 84.

34 Ibid, 1982, 84. 
of Bonhoeffer's Fanoe-Speech, the WCC Fifth Assembly in Nairobi in 1975 rebuked the churches to emphasise their readiness to live without the protection of armaments:

Christians must resist the temptation to resign themselves to a false sense of impotence or security. The churches should emphasise their readiness to live without the protection of armaments, and take a significant initiative in pressing for effective disarmament. Churches, individual Christians, and members of the public in all counties should press their governments to ensure national security without resorting to the use of weapons of mass destruction. ${ }^{35}$

It became the starting-point for church-related movements like Living without arms. In 1978 the CCIA cautioned that the human race is close to self-destruction. Dr Phillip Potter, general secretary of the WCC, addressing the UN first session on disarmament in 1978, noted amongst others that disarmament is an integral part of the struggle for a just, participatory and sustainable society. ${ }^{36}$ The Third WCC Assembly, New Delhi, 1961, Fourth WCC Assembly, Uppsala, 1998, Geneva, 1968, Fifth Assembly of the WCC, Nairobi, 1975, emphasised on the one hand that total disarmament is the goal, but affirmed that it is a complex and long-term process. In 1979 the Central Committee of the WCC adopted a Programme for the disarmament and against militarism and the arms race. ${ }^{37}$ The Central Committee affirmed that the quest for peace and disarmament is an integral part of the struggle for justice and human dignity. ${ }^{38}$ The armed race was seen as interlinked to issues of development, justice and human rights. The WCC's premise was that peaceful settlement of all international conflicts, as the only alternative to avoid war or use of force, should be generally recognised and accepted. ${ }^{39}$ The WCC Central Committee in Jamaica admitted that religious factors and theological interpretations contributed to the growth of militarism. The Central Committee furthermore stated that Christians have a prophetic task to denounce both the structures of injustice, which promote and sustain militarism in the world, and those who misuse the power they have acquired to maintain these structures. They stated that there is no place for a militarism which claims to defend the 'true faith'; there isn't any justification for the distorted concepts of national security; there is no place for trade in arms or techniques of oppression. ${ }^{40}$ The WCC Executive Committee called upon member churches to initiate and encourage measures for peaceful resolutions of conflicts. The Central Committee of the WCC expressed in August 1980 its continuing concern regarding

35 Ibid, 1982, 83.

36 Peace and disarmament. Documents of the World Council of Churches 1982, 87.

37 Nairobi to Vancouver 1975-1983. Report of the Central Committee to the Sixth Assembly of the WCC. Geneva. 1983, 123.

38 Ibid, 1983, 124.

39 Peace and disarmament 1982, 95.

40 Ibid, 1982, 95. 
prevailing threats to peace and urged that peaceful solutions should be reached through negotiations. ${ }^{41}$

The WCC renewed their commitment to justice and peace at the Sixth WCC Assembly in Vancouver, Canada, $1983 .{ }^{42}$ A conciliar process of mutual commitment to justice, peace and integrity of creation was emphasised at the Assembly. The WCC stated that "without justice for all everywhere we shall never have peace anywhere' ${ }^{43}$ Special emphasis was placed on the peaceful resolutions of conflicts. ${ }^{44}$ One of the most comprehensive statements on the subject was issued by the Vancouver Assembly, namely:

Peace is not just the absence of war. Peace cannot be built on foundations of injustice. Peace requires a new international order based on justice for and within all nations, and respect for the God-given humanity and dignity of every person. Peace is, as the prophet Isaiah has taught us, the effect of righteousness. ${ }^{45}$

The Assembly furthermore unequivocally declared the production and deployment as well as the use of nuclear weapons as a crime against humanity and condemned such activities on ethical and theological grounds. ${ }^{46}$

The World Convocation on justice, peace and the integrity of the creation which took place during 1990 in Seoul, Korea, affirmed a call to seek every possible means of establishing, achieving peace and solving conflicts by non-violent actions. The Convocation committed to practise non-violence in all personal relationships, to work for the banning of war as a legally recognised means of resolving conflicts and to press governments for the establishment of an international order of peacemaking. ${ }^{47}$ Programmes for protection and empowerment, for example the Ecumenical monitoring programme for South Africa (EMPSA), 1993-1995, and Ecumenical accompaniment programme in Palestine and Israel (EAPPI), 2001-2011, impacted the discourse on the prevention of violent conflict and the generation of non-violent social change.

\section{HISTORIC PEACE CHURCHES}

Several of the Historic Peace Churches (for example the Church of the Brethren and the Dutch Mennonites and German Mennonites) are founding members of the

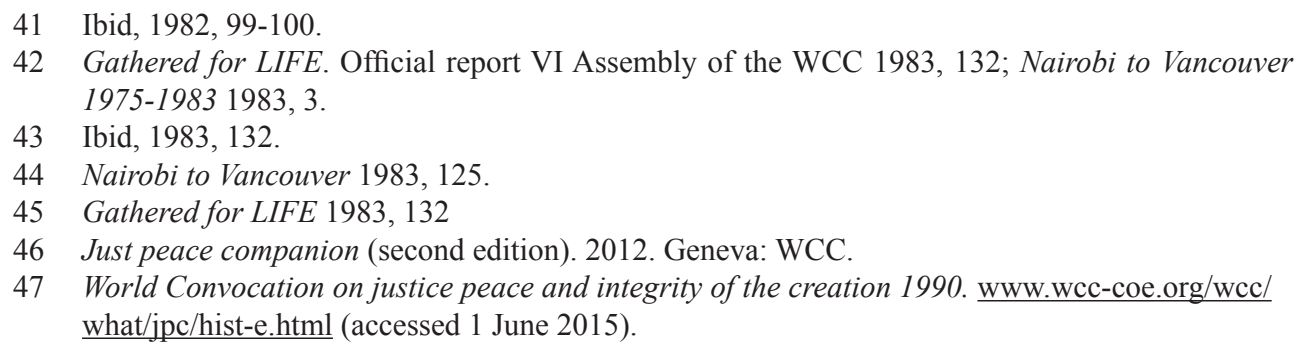


WCC. The Religious Society of Friends (popularly known as Quakers), Mennonites and the Bretheren are known for their refusal to take part in war (Bainton 1982, 152). In 1949 the Bretheren Service in Europe, the Peace Churches in Europe, along with Religious Society of Friends from the United Kingdom and officials of the International Fellowship of Reconciliation (IFOR), came together to organise a European Continuation Committee of Historic Peace Churches. This initiative arose from a meeting of representatives from the Historic Peace Churches and from the WCC staff in Geneva (including the later General Secretary, Philip Potter). The WCC awaited the joint response of the Historic Peace Churches on the WCC statement War is contrary to the will of God. The European Continuation Committee of the Historic Peace Churches co-organised and sponsored a series of theological dialogues that is known as the Puidoux Conferences, named after the town where the first meeting took place (Enns 2010, 1). There had been four major meetings: Puidoux, Czechoslovakia (1955); Iserlohn, Germany (1957); Bièvres, France (1960); and Oud Poulgeest, Netherlands (1962).

The Historic Peace Churches, namely the Church of the Brethren, Mennonites and Religious Society of Friends, have been conscientiously opposed to military violence throughout their histories. On 2-7 August 1960 in Bièvres, France, theologians from Eastern Europe joined the Puidoux reflections for the first time. During the period between the World Wars the issues of pacifism sharpened (Nicholson 1984, 78). These conferences (1955-1962) were the first substantial theological dialogues between members of Anabaptist-related churches and mainline Protestants since the sixteenth century (Durnbaugh 2003, 371). The backdrop for the Puidoux meetings was the sustained attempt by Historic Peace Church leaders to engage the WCC in meaningful conversations on appropriate Christian response to the issues of war, peace and justice (Durnbaugh 2003, 373). Professors from mainline churches joined the Historic Peace Churches' scholars for debate on the interdependence between ecclesiology and peace ethics.

In 1953 the Continuation Committee of the Historic Peace Churches submitted a statement to the WCC entitled Peace is the will of God. In this statement the Historic Peace Churches state that regarding war, the agreement amongst them is unanimous that war is fundamentally at variance with the real spirit, attitude and ethic of Jesus. Their premise is that the direct intent of the words of Christ and of the New Testament would preclude the execution of warfare. They hold it that since war is contrary to the will of God, it should be incumbent for every Christian to live accordingly. The Historic Peace Churches, the Anabaptist, embrace the refusal of war based on their understanding of the New Testament and the way of Christ (Ferguson 1977, 113). They uphold that all war is sin, whether committed by Christians or non-Christians, and therefore war as a method of settling international disputes is wrong. Their premise is that the church's most effective witness against war is not the statements she makes against it, the legislation she influences, the conferences she holds, nor 
even the sermons she preaches, but simply that which she herself is and does, in her own members. Disarmament on the part of a nation has been seen by the Historic Peace Churches as an act of faith that entails the risk of exploitation by a stronger power. They therefore hold that the refusal to participate in and to support war in any form is the only course for the Christian (that is) compatible with the gospel of Jesus Christ. They furthermore urge the WCC to take steps to challenge world Christendom to a basic reconsideration of its traditional position of war. ${ }^{48}$

One of the crucial questions of the Puidoux Conference was, if Christ is Lord, he is Lord over church and state. In 1955 the Historic Peace Churches issued a statement: The Lordship of Christ over church and state. For Mennonites, this implied that the church's first duty is to confess this fact and to live in discipleship. Their premise was that the church should not assume power to wage war, since Christ is Lord, not the church. For the opposite side, this confession of the Lordship of Christ led to the basic conclusion that there is no power that is not granted by this Lord. Christ rules the world through worldly institutions, which might in the end include the possibility of waging war in order to defend the innocent and to fight the evildoers. The Historic Peace Churches critiqued the symbiosis between church and state. In July 1965 fundamental tensions emerged during the Puidoux Conference, namely support for military intervention as a last resort versus a categorical refusal of violence; commitment to non-violence as an individual versus as a community or a church. Further reflection on this issue was entrusted to a smaller study commission. ${ }^{49}$

John Howard Yoder, a native of Ohio, Mennonite from background, emerged during this period as the spokesperson of the Historic Peace Churches on the issue of just war and just peace. According to Yoder (1972a, 205) the instructions to the Romans in Romans 13:1-7 to be subjected to a government in whose administration they had no voice, does not mean that Christians are called to do military service or police service. The function of bearing the sword to which Christians are called to subject according to Yoder, does not refer to death penalty or war. He extensively attends to this theme in his writings. According to Yoder $(1972 b, 96)$ the fact that he put Christian hope in the centre of theological deliberation at Evanston, is a recognition that history and human endeavour can be understood only in terms of God's plan. A commitment to non-violent action for justice and reconciliation is seen by the Historic Peace Churches as a mark of the church. At the third Puidoux Conference, held near Paris at Bievres, Yoder issued sharp criticism of the traditional just-war theory, or as he later preferred to call it, the 'justifiable war' theory. He articulated with precision the merits and limits of the just-war theory. Yoder's

48 Peace is the will of God, submission by the 'Historic Peace Churches' to the World Council of Churches, 1952 (accessed 1 June 2015).

49 Church and peace. http://www.church-and-peace.org/timeline.html The Conrad Grebel Review 23(3 Winter 2010). https://uwaterloo.ca/grebel/publications/conrad-grebel-review/issues/ fall-2005/peace-church-dialogue-and-diversity-ecumenical-movement (accessed 1 June 2015). 
contention was that pacifists and those holding to the just-war principles have much in common (Durnbaugh 2003, 371).

\section{TRANSFORMING THE GLOBAL CULTURE OF VIOLENCE IN THE DIRECTION OF A CULTURE OF JUST PEACE}

Since the Seventh WCC Assembly which met in Canberra in February 1991, the WCC has emphasised the transformation of the global culture of violence in the direction of just peace. This Assembly took place whilst on the one side the Gulf War was raging and on the other side the world saw the dawn of the Soviet Union and the Cold War. ${ }^{50}$ The WCC Central Committee in Johannesburg, 1994, established a Programme to overcome violence. From here on the influence of the Historic Peace Churches can be distinguished clearly in the deliberations regarding justice and peace in the WCC. The Central Committee also declared the need to confront and overcome the spirit, logic and practice of war and to develop new theological approaches consonant with the teaching of Christ, which start not with war, and which move to peace, but with the need for justice. ${ }^{51}$

The WCC General Assembly at Harare, 1998, affirmed that they will work together to be agents of reconciliation and peace with justice on local level, as well as in the political, social and economic structures at global level. They asserted to build a culture of peace that is based on just, sustainable communities. The WCC Assembly 1998 called for a Decade to Overcome Violence: Churches seeking reconciliation and peace (DOV) 2001-2010. The DOV was a global movement that attempted to strengthen existing efforts and networks for preventing and overcoming violence, as well as to inspire the creation of new ones. It is in the DOV that the influence of the Historic Peace Churches can easily be discerned. For example, the WCC urged churches to face the challenge to give up any theological or any other justification of the use of military power, and to become a koinonia dedicated to the pursuit of just peace. The DOV calls the churches to work together for peace, justice and reconciliation at local, regional and global level; to embrace creative approaches to peace building which are consonant with the spirit of the gospel; to interact and collaborate with local communities, civil society actors and people of other living faiths, so as to prevent violence and promote a culture of peace; to walk with people who are systematically oppressed by violence, and to act in solidarity with all struggling for justice, peace and the integrity of creation; to repent for our complicity in violence and to engage in theological reflection to overcome the spirit, logic, and

50 Raiser, K. The United Nations and the WCC: Rights and justice. http://www.thefreelibrary. $\mathrm{com} /$ The+United+Nations+and+the+WCC\%3a+rights+and+justice.-a017386905 p. 279-281 (accessed 1 June 2015).

51 Just peace companion 2012, 16. 
practice of violence. ${ }^{52}$ The WCC hereby overtly moved from a just-war position to a just-peace position. The International Historic Peace Church Consultation Theology and culture: Peacemaking in a globalized world at Bienenberg Theological Seminary, Switzerland, 25-29 June 2001, stated regarding the DOV that the search for peace is not the possession of the Peace Churches, but is a deep, common yearning of all Christians, people of other faiths and all of humanity.

The DOV sought to establish points of contact with the relevant aims, programmes and initiatives within the United Nations decade for a culture of peace and nonviolence for the children of the world (2001-2010). In 2001 the CCIA meeting in Trans-Montana, Switzerland, renewed the appeal to the churches of the WCC General Assembly at Nairobi, 1975, concerning the readiness of the churches to live without the protection of armaments and to take a significant initiative in pressing for effective disarmament. The CCIA urged Christians to foster the development of social and political institutions that provide security and physical and spiritual wellbeing for all without resort to weapons.

The Ninth WCC Assembly, Porte Alegre Brazil, 2006, committed to a profound common ethical-theological reflection and advocacy for non-violent conflict prevention, a civilian conflict management and peace consolidation. The Assembly also noted that the praxis of non-violence should be rooted in a spirituality that acknowledges one's own vulnerability, that encourages and empowers the powerless to be able to face up to those who misuse power.

\section{MOVING PEACE TO THE CENTRE OF LIFE AND WITNESS OF THE CHURCH}

At the Central Committee, Geneva Switzerland, 2011, building on the notion of just peace, an Ecumenical call for just peace had been drafted for serious consideration by its member churches and final confirmation at Busan Assembly in 2013. The Ecumenical call for just peace was issued in response to the Assembly's recommendation on just peace in Porto Alegre Brazil, 2006. It moves peace to the centre of life and witness of the church. This call builds on insights gained in the course of the DOV, 2001-2010. Furthermore the call emphasises that just peace embodies a fundamental shift in ethical practice. It implies a different framework of analysis and criteria for action. This call signals a fundamental shift and indicates some of the implications for the life and witness of the churches.

A resource document, the Just peace companion, issued at the WCC Assembly 2013 to member churches, presents biblical, theological and ethical considerations, proposals for further exploration and examples of good practice. 'Just peace may be comprehended as a collective and dynamic yet grounded process of freeing human

52 Decade to Overcome Violence. http://www.overcomingviolence.org/en/decade-to-overcomeviolence /about-dov.html (accessed 1 June 2015). 
beings from fear and want, of overcoming enmity, discrimination and oppression, and of establishing conditions for just relationships that privilege the experience of the most vulnerable and respect the integrity of creation. ${ }^{53}$ Above documents, together with the commitments arising from the International Ecumenical Peace Convocation in Kingston, Jamaica, in May 2011, under the theme Glory to God and peace on earth assisted the Assembly of the WCC 2013 to reach a new ecumenical consensus on justice and peace. The WCC urged churches to build trust and collaborate with other communities of faith and people of different world views to reduce national capacities for waging war; eliminate weapons that put humanity and the planet at unprecedented risk; and generally delegitimise the institution of war. At the International Ecumenical Peace Convocation (IEPC), Kingston, 2011, the journey to just peace as an international agenda was highlighted. A Statement on the way of just peace was adopted by the Tenth WCC Assembly held in Busan Korea in 2013. Amongst others, the Assembly affirmed just peace as a journey into God's purpose for humanity and all creation. ${ }^{54}$ The WCC emphasised that churches must work together to strengthen international human rights and humanitarian law; promote multilateral negotiations to resolve conflicts; hold governments responsible for ensuring treaty protections; help eliminate all weapons of mass destruction; and press for reallocation of unnecessary military budgets to civilian needs. ${ }^{55}$

The WCC Assembly 2013 also undertook a critical analysis of the Responsibility to prevent, react and rebuild programme $e^{56}$ in cooperation with member churches and specialised ministries. ${ }^{57}$ The Assembly therefore undertook to lead and accompany ecumenical just-peace ministries and networks in the practice of violence prevention, non-violence as a way of life, collective advocacy and the advancement of international norms, treaties and law. The WCC encouraged its member churches to engage in cooperative interfaith programmes in order to address conflicts in multi-ethnic and multi-religious societies. They also requested member churches and partners to develop communication strategies that advocate for justice and peace, proclaim the hope of transformation and speak truth to power. The WCC undertook to develop

53 Ecumenical call for just peace, p.7. http://www.overcomingviolence.org/en/resources-dov/wccresources/documents/declarations-on-just-peace/ecumenical-call-to-just-peace.html (accessed 1 June 2015).

54 What we do promoting just peace. http://www.oikoumene.org/en/what-we-do/promoting-justpeace (accessed 1 June 2015).

55 WCC Tenth Assembly. 2013. Statement on the way of just peace, Doc. No. PIC 02.4 p. 4 of 5.

56 It is a new doctrine adopted by the UN General Assembly and Security Council, and endorsed by the World Council of Churches, to address injustices like genocide, ethnic cleansing, war crimes and crimes against humanity, and explains why the responsibility to protect is essential for global peace and security. When a state is failing to protect its civilians, the responsibility to protect falls on the international community to prevent, react and rebuild areas affected by mass suffering and atrocities.

57 Responsibility to protect. http://www.responsibilitytoprotect.org/files/RMS\%20Education $\% 20$ Kit\%20Sheet\%202.pdf (accessed 1 June 2015). 
guidelines within the concept of 'economies of life' for the right sharing of resources and the prevention of structural violence, establishing useable indicators and benchmarks. The WCC also undertook to convene churches and related organisations to work for human rights protection through international treaty bodies and the United Nations Human Rights Council; to work for the elimination of nuclear and all other weapons of mass destruction, cooperating with the International campaign to abolish nuclear weapons; and to seek ratification of the Arms trade treaty by their respective governments and monitor its implementation. The WCC affirmed their decision to negotiate and establish a ban on the production, deployment, transfer and use of nuclear weapons in accordance with international humanitarian law and to ensure that all remaining stocks of chemical weapons are destroyed under the terms of the Chemical weapons convention and cluster munitions at the earliest possible date. Lastly, the WCC declared their support for a pre-emptive ban on drones and other robotic weapon systems that will select and strike targets without human intervention when operating in fully autonomous mode..$^{58}$

\section{CONCLUSION}

It became clear during the course of time that modern warfare, with its massive destruction, can no longer be considered just. The tradition of a just war, requiring a just cause and the use of just means is currently challenged. The WCC has moved during the past century from a just-war position to a just-peace position and in doing this the WCC remains true to its legacy as an advocate for justice, human rights and peace, and it has developed an appropriate Christian response to the issues of war, peace and justice. The Historic Peace Churches, with Yoder as their spokesperson, played a pivotal role in the ecumenical movement engaged in war, peace and justice issues, and in doing so contributed majorly to a peace church perspective in the overall ecumenical conversation on justice and peace.

\section{REFERENCES}

Bainton, R.H.1982. Christian attitudes towards war and peace: A historical survey and critical reevaluation. Nashville: Abington.

Barkat, A.M., 1970 (ed). Conflict and violence and peace. World Council of Churches study. No m8. 1970. Geneva: WCC.

Durnbaugh, D.F. 2003. John Howard Yoder's role in 'The Lordship of Christ over church and state' conferences. Mennonite Quarterly Review 77(3 July 2003): 371-386.

Eastman, P.E. 1949. The Amsterdam Assembly of the World Council of Churches an international legal order. The International Law Quarterly Winter 1948-9, 2: 674-677.

58 WCC Tenth Assembly. 2013. Statement on the way of just peace, p. 5 of 5. 
Ferguson, J. 1977. War and peace in the world religions. London: Sheldon Press.

Howell, L. 1982. Acting in faith: The World Council of Churches since 1975. Geneva: WCC.

Loetcher, F.W. 1944. Augustine's City of God. Theology Today 1(3): 313-325.

Miller, D.E. 2013. From just war to just peace. Richmond: Augustin Printing.

Nichols, B.J. 1976. Nairobi 1975: A crisis in faith for the WCC. Published by World Evangelical Fellowship, Theological Commission.

Nicholson, R.B. 1984. The emergence of the peace movements during two world wars and the churches responses. In Religion war and peace, edited by E.K. Mosothoane, L.L. Pato and L. Krezscmar. University of Transkei, p. 78.

Nurser, J. 2003. The ecumenical movement churches, global order and human rights 1938-1948. Human Rights Quarterly, 25(4).

Schaff, P. (ed). 1994. City of God (and) Christian Doctrine (A Select Library of the Christian Church: Nicene and Post-Nicene Fathers; First Series, Volume 2. Grand Rapids: Eerdmans Publishing Company.

Van den Bent, A.J. 1986. Christian response in a world of crisis: A brief history of the WCC's Commission of the Churches on international affairs.

WWC Fifth Assembly. Official report. 1975. Breaking barriers, Nairobi Geneva: WCC.

WWC First Assembly. Official report. 1948. Report of Section IV, the Church and the international disorder. Amsterdam, 1948, Geneva: WCC.

WWC Sixth Assembly. Official report 1983. Gathered for LIFE. Vancouver . Geneva: WCC.

WWC Sixth Assembly. Report of Central Committee. 1983. Nairobi to Vancouver 1975-1983. Geneva: WCC, p.124.

WWC. Documents of the World Council of Churches, Roman Catholic Church. 1982. Peace and disarmament. Geneva: WCC.

WWC. Just peace companion (second edition). 2012. Geneva: WCC.

Yoder, J.H. 1972a. Yoder the politics of Jesus. Michigan: Eerdsmans.

Yoder, J.H. 1972b. The original revolution: Essays on Christian pacifism. Scotdale: Herald Press.

Yoder, J.H. 1996. When war is unjust: Being honest in just-war thinking (second edition). Maryknoll, NY : Orbis.

\section{ELECTRONIC SOURCES (WCC MATERIAL IS}

\section{MOSTLY DIGITALISED)}

Church and peace. http://www.church-and-peace.org/timeline.html The Conrad Grebel Review 23, no. 3 (Winter 2010). https://uwaterloo.ca/grebel/publications/conrad-grebel-review/issues/ fall-2005/peace-church-dialogue-and-diversity-ecumenical-movement (accessed 1 June 2015).

Decade to Overcome Violence DOV. http://www.overcomingviolence.org/en/decade-to-overcomeviolence /about-dov. html Disarmament on the WCC Agenda 2003. http://ploughshares.ca/ wp-content/uploads/2003/11/WCCandDisarmament.pdf p2 (accessed 1 June 2015). 
Early Journal Content on JSTOR 1905. http://archive.org/stream/jstor-25752575/25752575_djvu. txt. p 190-199 (accessed 1 June 2015).

Ecumenical call for just peace. 1212. http://www.overcomingviolence.org/en/resources-dov/wccresources/documents/declarations-on-just-peace/ (accessed 1 June 2015).

Eisenach-Avignon Resolution, Eisenach, Germany, 1928. http://www.skr.org/wp-content/ uploads/2013/10/Worldpeacemap_131017_high_utfall_sk\%C3\%A4rm\%C3\%A4rken.pdf (accessed 1 June 2015).

Enns, F. 2010. The peace church: Dialogue and diversity in the ecumenical movement, The Conrad Grebel Review 23(3 Winter 2010) (accessed 1 June 2015).

Introducing the principles of just war theory. http://istep.sdsu.edu/documents/Lesson\%205\%20 Intro\%20to\%20Just\%20War\%20Theory.pdf (accessed 1 June 2015).

Just war theory. Encyclopedia of philosophy. http://www.iep.utm.edu/justwar/ (assessed 1 June 2014).

Life and work movement. http://www.interchurchcenter.org/sites/default/files/assets/ Life\&WorkMvmt.pdf (accessed 1 June 2015).

Peace is the will of God. Submission by the 'Historic Peace Churches' to the World Council of Churches, 1952.

Promoting just peace. http://www.oikoumene.org/en/what-we-do/promoting-just-peace (accessed 1 June 2015).

Raiser, K. 2003. The United Nations and the WCC: Rights and Justice. http://www.thefreelibrary. $\mathrm{com} /$ The+United+Nations+and+the+WCC, p. 279-281 (accessed 1 June 2015).

Responsibility to protect. http://www.responsibilitytoprotect.org/ pdf (accessed 1 June 2015).

The development of common positions on justice, peace and creation in the ecumenical movement. http://oikoumene.net/hostudies/gerecht.book/ (accessed 1 June 2015).

Universal Christian Conference on life and work, Stockholm Sweden, 1925. http://www.archives. wcc-coe.org/query/detail.aspx?ID=80280 (accessed 1 June 2015).

WCC Tenth Assembly. 2013. Statement on the way of just peace, Doc. No. PIC 02.4 p. 4 of 5 Geneva: WCC.

What we do promoting just peace. http://www.oikoumene.org/en/what-we-do/promoting-justpeace (accessed 1 June 2015).

Williams, R. 2006. Jus Post Bellum: Just war theory and the principles of just peace. International studies perspectives [1528-3577] 7(4) (accessed 1 June 2015).

World alliance for promoting international friendship through the churches, 1909-1948. http:// archives.wcc-coe.org/query/detail.aspx?ID=40897 (accessed 1 June 2015).

World Convocation on justice peace and integrity of the creation 1990. http://www.wcc-coe.org/ wcc/what/jpc/hist-e.html (accessed 1 June 2015). 